\title{
An Empirical Research on the College Students' Orientation of Postgraduate Entrance Exam
}

\author{
Wei Zhao ${ }^{1, \text { a }}$ \\ ${ }^{1}$ School of Public Affairs \& Law, Southwest Jiaotong University, Chengdu City, Sichuan Province, \\ China
}

aWzhao_1@126.com

Keywords: college students, postgraduate entrance exam, orientation.

\begin{abstract}
Different orientations on postgraduate entrance exam of college students directly affect the quality of postgraduate education. This paper aims to guide and use these orientations appropriately based on analyzing the craze of postgraduate entrance exam in China. Various orientations on postgraduate entrance exam are investigated, and several related problems are found. Then the author analyzes these problems and puts forward to corresponding countermeasures and suggestions, in order to guide students' rational orientation of postgraduate entrance examination. This paper has certain significance and is helpful to students, universities and educators, as well as relevant social sectors.
\end{abstract}

\section{Introduction}

With the continuous development of Chinese economy, the scales of higher education and postgraduate education are expanding year by year. "Postgraduate Entrance Exam" has become a popular expression in campus and even the whole society. For many college students, the postgraduate entrance examination has become a practical issue they have to be faced with. In 2014 and 2015, the number of postgraduate entrance examination candidates decreased. But in 2016, the number of postgraduate candidates was 1.77 million, increased by $7 \%$ than 2015 . According to relevant statistics, since the end of last century, the number of postgraduate entrance examination candidates in China has increased enormously. In 1994 the number was 117 thousand. Now after less than 20 years, the number has increased more than ten times.

The craze for graduate school heats up in the 21st century, and becomes a hot topic in the academic field. May scholars begin to research this phenomenon from different perspectives. Some scholars use the theory of economics, and analyze students' choice as a kind of economic behavior. For example, Ni-juan Xiong, Dong-hui Zhao , Zu-lin Shi and Bao-ying Zhang use indicators like the internal rate of return, net present values of cost and profit and Mencerian Return to measure the comparative advantage between undergraduate employees and postgraduate employees.[1][2] Cheng-mei Yin believes that, the advantages of graduate education, the superior conditions of cities, employers' demands and the favorable treatments are external causes which lead students to continue with graduate education.[3] Hai-liang Wang analyze the craze for graduate school from the perspective of social cognition, and finds the following cognition of students. National policies attach great importance to graduate education; employers need more high level talents; the employment situation is bad; enrollment scale expands; students need to realize personal development. Based on these ideas, college students decide to take the postgraduate entrance examination. [4]

Different orientations on postgraduate entrance exam of college students directly affect the quality of postgraduate education. This paper aims to guide and use these orientations appropriately based on analyzing the craze of postgraduate entrance exam in China. Various orientations on postgraduate entrance exam are investigated, and several related problems are found. Then the author analyzes these problems and puts forward to corresponding countermeasures and suggestions, in order to guide students' rational orientation of postgraduate entrance examination. This paper has certain significance and is helpful to students, universities and educators, as well as relevant social sectors. 


\section{Research Process}

Questionnaire design and survey. Based on the background, purpose and significance of this research, the investigation is carried out through random sampling methods. Research subjects are 300 senior students randomly selected from different majors in Southwest Jiaotong University. 332 copies of questionnaire are issued, 310 are recovered, among which 300 copies are valid questionnaires.

Questions in this questionnaire are divided into two parts: the orientation section and the expectation section. In the orientation section, questions on students' satisfactions level on their majors and schools, the reasons of choosing postgraduate education, and the analysis of their postgraduate majors are listed.

Analysis of survey results. Gender analysis on students' decision of taking postgraduate entrance examination

Table 1

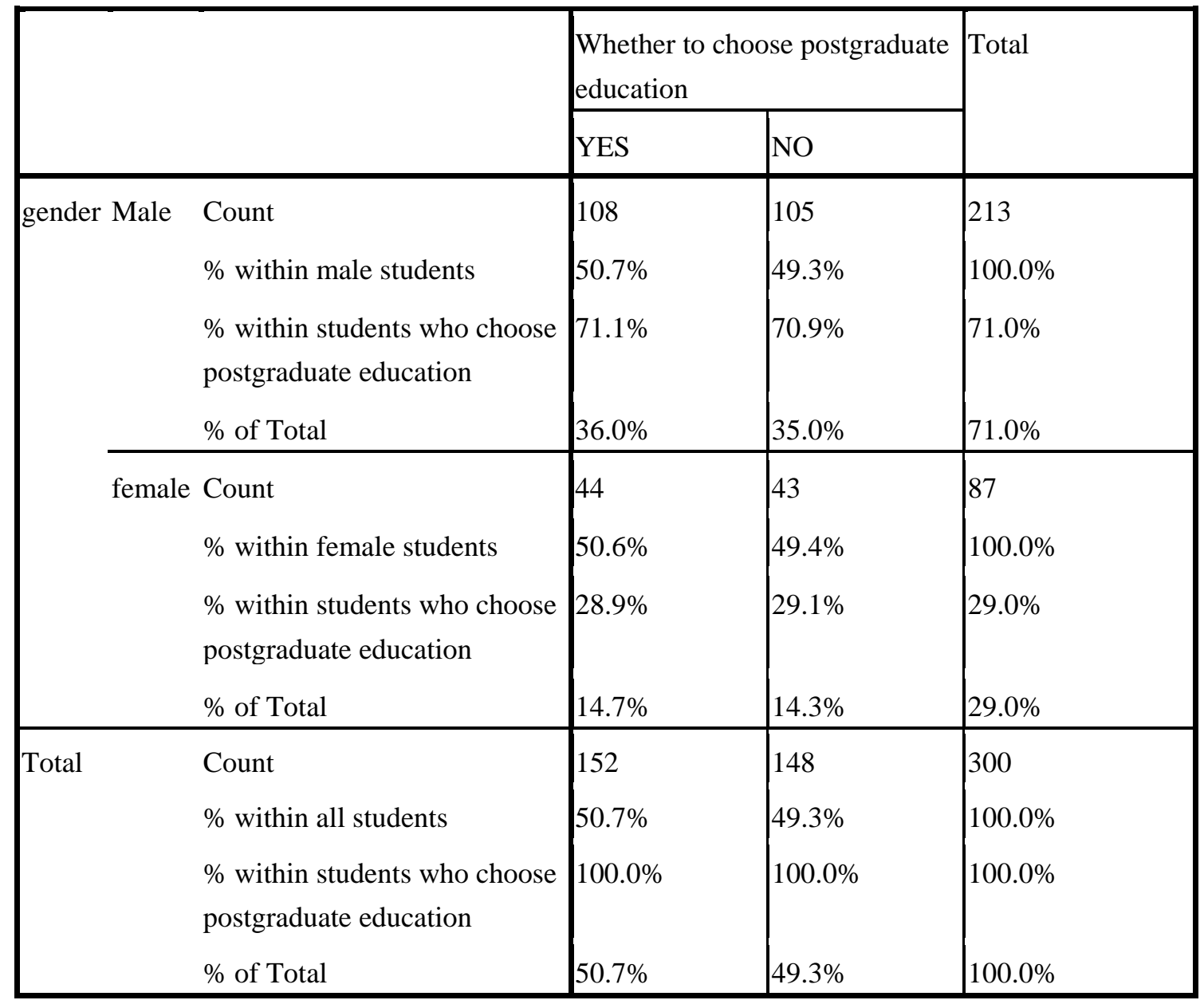

From Table 1, we can find that

108 male students choose postgraduate education, accounting for $50.7 \%$ of total male students, $71.1 \%$ of total students who choose postgraduate education, and $36 \%$ of total subjects; 105 male students do not choose postgraduate education, accounting for $49.3 \%$ of total male students, $70.9 \%$ of total students who do not choose postgraduate education, and 35\% of total subjects.

44 female students choose postgraduate education, accounting for $50.6 \%$ of total female students, $28.9 \%$ of total students who choose postgraduate education, and $14.7 \%$ of total subjects; 43 female students do not choose postgraduate education, accounting for $49.4 \%$ of total female students, $29.1 \%$ of total students who do not choose postgraduate education, and $14.3 \%$ of total subjects.

In all students, 152 choose to continue their studies, accounting for $50.7 \%$ of total number; 148 students do not want to take post graduate entrance exam, accounting for $49.3 \%$ of total students. 
In summary, nearly half of these students choose postgraduate education, which is a relatively large portion. At the same time, the numbers of male and female students who choose postgraduate education are roughly the same. The basic reason for this phenomenon goes as follows. Now the employment pressure increases; big companies tend to recruit higher-level candidates. Only the students who have enriched themselves can better adapt to the rapidly developed society. Many students believe that the expected income after postgraduate graduation is greater than the income of direct employment. At the same time, high-level talents have cost advantages in the regional transfer, which promote a part of people to choose postgraduate education in order to move to developed regions.

Analysis on the decision of taking postgraduate entrance examination from the perspective of family economic conditions

Frequency analyses of different groups according to family economic situations

Table 2. Crosstabulation of family economic situations and whether to choose postgraduate education

\begin{tabular}{|c|c|c|c|c|c|}
\hline & & & $\begin{array}{r}\text { whether to choose } \mathbf{F} \\
\text { educatio }\end{array}$ & graduate & \\
\hline & & & YES & NO & Total \\
\hline Family & wealthy & Count & 7 & 8 & 15 \\
\hline economic & & $\%$ within wealthy students & $46.7 \%$ & $53.3 \%$ & $100.0 \%$ \\
\hline & & $\begin{array}{l}\% \text { within students who choose } \\
\text { postgraduate education }\end{array}$ & $4.6 \%$ & $5.4 \%$ & $5.0 \%$ \\
\hline & & $\%$ of Total & $2.3 \%$ & $2.7 \%$ & $5.0 \%$ \\
\hline & Ordinary & Count & 116 & 95 & 211 \\
\hline & & $\%$ within ordinary students & $55.0 \%$ & $45.0 \%$ & $100.0 \%$ \\
\hline & & $\begin{array}{l}\% \text { within students who choose } \\
\text { postgraduate education }\end{array}$ & $76.3 \%$ & $64.2 \%$ & $70.3 \%$ \\
\hline & & $\%$ of Total & $38.7 \%$ & $31.7 \%$ & $70.3 \%$ \\
\hline & Relatively & Count & 23 & 35 & 58 \\
\hline & poor & $\begin{array}{l}\% \text { within relatively poor } \\
\text { students }\end{array}$ & $39.7 \%$ & $60.3 \%$ & $100.0 \%$ \\
\hline & & $\begin{array}{l}\% \text { within students who choose } \\
\text { postgraduate education }\end{array}$ & $15.1 \%$ & $23.6 \%$ & $19.3 \%$ \\
\hline & & $\%$ of Total & $7.7 \%$ & $11.7 \%$ & $19.3 \%$ \\
\hline & poor & Count & 6 & 10 & 16 \\
\hline & & \% within poor students & $37.5 \%$ & $62.5 \%$ & $100.0 \%$ \\
\hline & & $\begin{array}{l}\% \text { within students who choose } \\
\text { postgraduate education }\end{array}$ & $3.9 \%$ & $6.8 \%$ & $5.3 \%$ \\
\hline & & $\%$ of Total & $2.0 \%$ & $3.3 \%$ & $5.3 \%$ \\
\hline Total & & Count & 152 & 148 & 300 \\
\hline & & $\%$ within the given situation & $50.7 \%$ & $49.3 \%$ & $100.0 \%$ \\
\hline
\end{tabular}




\begin{tabular}{|l|r|r|r|}
\hline $\begin{array}{l}\text { \% within students who choose } \\
\text { postgraduate education }\end{array}$ & $100.0 \%$ & $100.0 \%$ & $100.0 \%$ \\
\% of Total & $50.7 \%$ & $49.3 \%$ & $100.0 \%$ \\
\hline
\end{tabular}

As we can see from Table 2:

7 students from wealthy families choose postgraduate education, accounting for $46.7 \%$ of wealthy students, $4.6 \%$ of total students who choose postgraduate education, and 2.3\% of total subjects; 8 students from wealthy families do not choose postgraduate education, accounting for $53.3 \%$ of total wealthy students, $5.4 \%$ of total students who do not choose postgraduate education, and $2.7 \%$ of total subjects.

116 students from ordinary families choose postgraduate education, accounting for $55.0 \%$ of ordinary students, $76.3 \%$ of total students who choose postgraduate education, and $38.7 \%$ of total subjects; 95 students from ordinary families do not choose postgraduate education, accounting for $45.0 \%$ of total ordinary students, $64.2 \%$ of total students who do not choose postgraduate education, and $31.7 \%$ of total subjects.

23 students from relatively poor families choose postgraduate education, accounting for $39.7 \%$ of relatively poor students, $15.1 \%$ of total students who choose postgraduate education, and $7.7 \%$ of total subjects; 35 students from relatively poor families do not choose postgraduate education, accounting for $60.3 \%$ of total relatively poor students, $23.6 \%$ of total students who do not choose postgraduate education, and $11.7 \%$ of total subjects.

6 students from poor families choose postgraduate education, accounting for $37.5 \%$ of poor students, $3.9 \%$ of total students who choose postgraduate education, and $2.0 \%$ of total subjects; 10 students from poor families do not choose postgraduate education, accounting for $62.5 \%$ of total poor students, $6.8 \%$ of total students who do not choose postgraduate education, and $3.3 \%$ of total subjects.

In summary, students from ordinary families are more willing to continue their studies. More students from wealthy and poor families do not want to choose postgraduate education. For students from wealthy families, employment pressure and economic problems are not the main reasons which can influence their decisions. As a kind of social mobility mechanism, education helps people with high educational levels to get higher social statuses. From this aspect, it is a rational choice for college students to continue with their studies in order to improve their self-values and flow to elite society.

Analysis of variance according to family economic situations

Table 3. ANOVA

\begin{tabular}{|l|r|r|r|r|r|}
\cline { 2 - 6 } & & & & & \\
\hline $\begin{array}{l}\text { Family economic } \\
\text { situation }\end{array}$ & Sum of Squares & df & Mean Square & F & \multicolumn{1}{c|}{ Sig. } \\
\hline Between Groups & 1.334 & 1 & 1.334 & 3.399 & .066 \\
Within Groups & 116.916 & 298 & .392 & & \\
Total & 118.250 & 299 & & & \\
\hline
\end{tabular}

From Table 3, we can see that, the significant probability of $\mathrm{P}=0.066>0.05$, which means there is no significant difference between the family economic situations and the choice of taking postgraduate entrance examination.

Relevant analysis according to students' undergraduate majors2.2.3.1 Analysis of variance according to students' undergraduate majors 
Table 4. ANOVA

\begin{tabular}{|l|r|r|r|r|r|}
\cline { 2 - 6 } Undergraduate major & & & & & \\
\hline Between Groups & Sum of Squares & df & Mean Square & F & Sig. \\
Within Groups & 2.263 & 1 & 2.263 & 5.241 & .023 \\
Total & 128.684 & 298 & .432 & & \\
\hline
\end{tabular}

From Table 4, we can seen, the significant probability of $\mathrm{P}=0.023<0.05$, which means there is significant difference between students' undergraduate majors and the choice of taking postgraduate entrance examination.

Table 5. Crosstabulation of undergraduate majors and factors on school selection

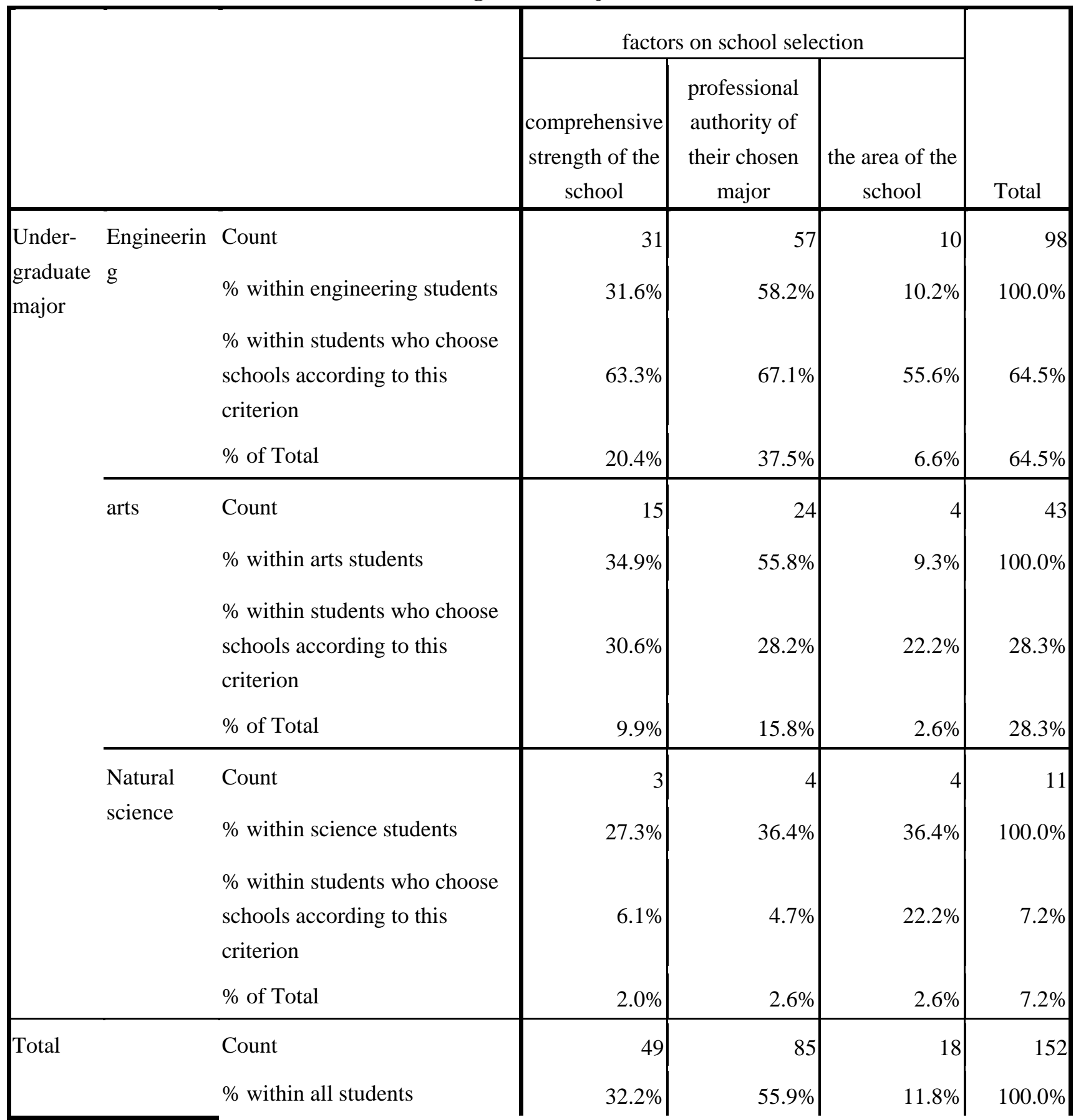




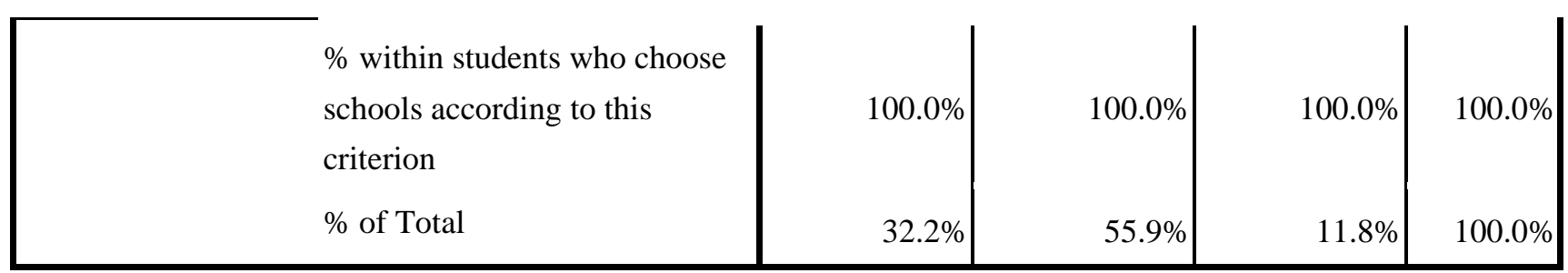

Frequency analyses of different groups on school selection according to students' majors

We can draw following conclusions from the table:

31 engineering students choose schools according to the comprehensive strength of the university, accounting for $31.6 \%$ of total engineering students, $63.3 \%$ of total students who choose schools according to the comprehensive strength of the university, and $20.4 \%$ of total subjects; 57 engineering students choose schools according to the professional authority of their chosen majors, accounting for $58.2 \%$ of total engineering students, $67.1 \%$ of total students who choose schools according to this criterion, and $37.5 \%$ of total subjects; 10 engineering students choose schools according to the area of the school, accounting for $10.2 \%$ of total engineering students, $55.6 \%$ of total students who choose schools according to this criterion, and $6.6 \%$ of total subjects.

15 arts students choose schools according to the comprehensive strength of the university, accounting for $34.9 \%$ of total arts students, $30.6 \%$ of students who choose schools according to the comprehensive strength of the university, and 9.9\% of total subjects; 24 arts students choose schools according to the professional authority of their chosen majors, accounting for $55.8 \%$ of total arts students, $28.2 \%$ of total students who choose schools according to this criterion, and $15.8 \%$ of total subjects; 4 arts students choose schools according to the area of the school, accounting for $9.3 \%$ of total arts students, $22.2 \%$ of total students who choose schools according to this criterion, and $2.6 \%$ of total subjects.

3 science students choose schools according to the comprehensive strength of the university, accounting for $27.3 \%$ of total science students, $6.1 \%$ of total students who choose schools according to the comprehensive strength of the university, and $2.0 \%$ of the total subjects; 4 science students choose schools according to the professional authority of their chosen major, accounting for $36.4 \%$ of the total science students, $4.7 \%$ of total students who choose schools according to this criterion, and $2.6 \%$ of the total subjects; 4 science students choose schools according to the area of the school, accounting for $36.4 \%$ of the total science students, $22.2 \%$ of total students who choose schools according to this criterion, and $2.6 \%$ of total subjects.

In conclusion, students pay more attention to professional authority of their chosen major than the comprehensive strength and area of the school; that is, the major is more important than the university. The bar chart below clearly shows this preference.

Table 6 


\section{Bar Chart}

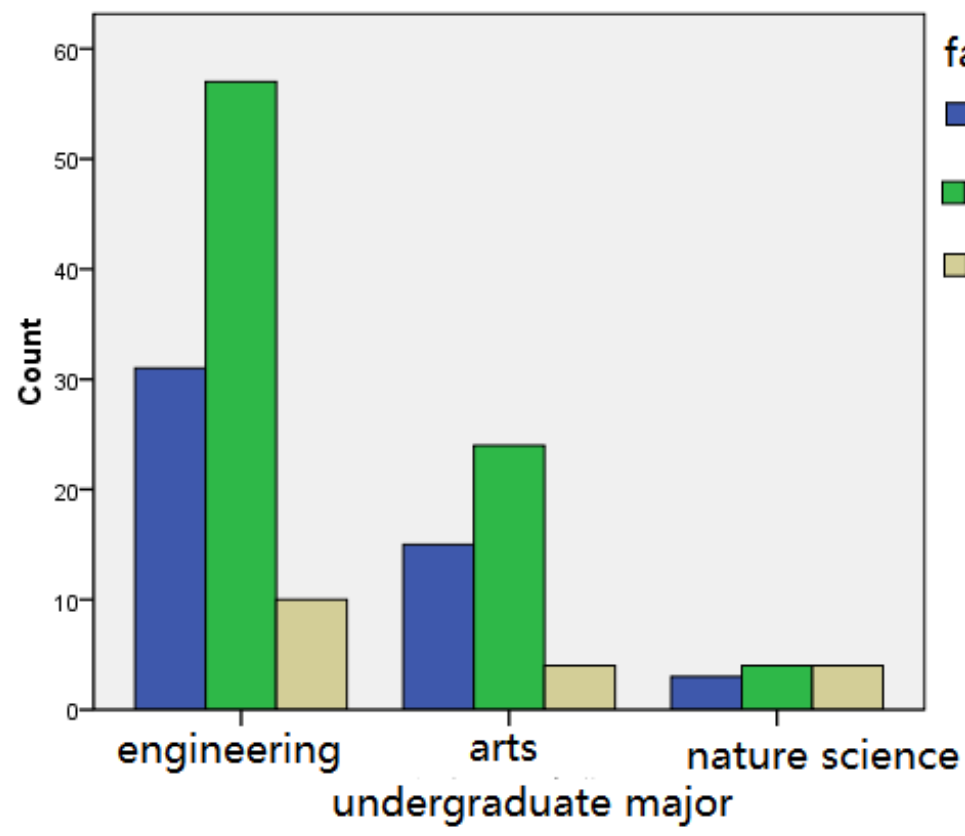

factors on school selection

comprehensive strength of the school

professional authority of

their chosen major

$\square$ the area of the school

Analysis on students' motivation of choosing postgraduate education

Table 7. Main motivation

\begin{tabular}{|c|c|c|c|c|c|}
\hline & & Frequency & Percent & Valid Percent & $\begin{array}{c}\text { Cumulative } \\
\text { Percent }\end{array}$ \\
\hline $\begin{array}{l}\text { Missing } \\
\text { Total }\end{array}$ & $\begin{array}{l}\text { further study to improve } \\
\text { personal quality } \\
\text { alleviating the employment } \\
\text { pressure } \\
\text { conformist mentality } \\
\text { better personal connections } \\
\text { studying a major different } \\
\text { from undergraduate years } \\
\text { Total } \\
\text { System }\end{array}$ & $\begin{array}{r}89 \\
31 \\
8 \\
6 \\
18 \\
152 \\
148 \\
300\end{array}$ & $\begin{array}{r}29.7 \\
10.3 \\
2.7 \\
2.0 \\
6.0 \\
50.7 \\
49.3 \\
100.0\end{array}$ & $\begin{array}{r}58.6 \\
20.4 \\
5.3 \\
3.9 \\
11.8 \\
100.0\end{array}$ & $\begin{array}{c}58.6 \\
78.9 \\
84.2 \\
88.2 \\
100.0\end{array}$ \\
\hline
\end{tabular}

According to the table, we can see that most students want to continue their studies and improve their personal qualities through postgraduate education; a part of students want to relieve the employment pressure; some other students want to continue to study their beloved majors; only a small part of students choose to continue their studies out of other people's influences or the demanding of getting more personal connections. These results reflect students' demands of self enrichment.

Analysis on students' expectations of choosing postgraduate education 
Table 8. Expectations of postgraduate education

\begin{tabular}{|ll|r|r|r|r|}
\hline & Frequency & Percent & Valid Percent & $\begin{array}{c}\text { Cumulative } \\
\text { Percent }\end{array}$ \\
\hline Valid $\quad$ Master degree & 39 & 13.0 & 25.7 & 25.7 \\
& $\begin{array}{l}\text { total improvement } \\
\text { of personal quality }\end{array}$ & 93 & 31.0 & 61.2 & 86.8 \\
$\begin{array}{l}\text { Better personal } \\
\text { connections }\end{array}$ & 20 & 6.7 & 13.2 & 100.0 \\
Total & 152 & 50.7 & 100.0 & \\
Missing System & 148 & 49.3 & & \\
Total $\quad 300$ & 100.0 & & \\
\hline
\end{tabular}

From the table we can see that, more than half of students who choose postgraduate study want to get a comprehensive improvement of their personal qualities, and basically the same number of students mainly expects to get master degree or wants to achieve better human resources. This is because the employment situation is becoming more severe. The improvement of personal quality is an effective measure to deal with social competition, and can lay a good foundation for their future development.

\section{Conclusion and Recommendations}

Combing this investigation with the practical situation, we analyze and summarize the following points about university students' orientations of choosing postgraduate education, and put forward to some corresponding suggestions, hoping to help students to cope with this issue with correct attitudes.

Characteristics of students' postgraduate entrance examination orientation. Basically the same number of male and female students chooses to take postgraduate entrance examination. This shows that with the progress of the society, the number of female students who want to pursue higher education increases significantly. These girls want to have higher degrees, improve their personal qualities, and enhance their competitiveness in work field. The relatively severe employment situation, the preference of government policy and the increasing demand of high-level talents in the society are main reasons which lead students to choose postgraduate study.

Students from ordinary families are more inclined to choose postgraduate education, accounting for $70 \%$ of total students who want to continue their studies. They form the main body of the sharply increasing army of postgraduate candidates in recent years. Relatively speaking, only a few of students from wealthy families and financially difficult families choose to continue their studies; the proportions are comparatively stable. Possible reasons go as follows. Students from f wealthy families have better job opportunities and higher starting points. Students from financially difficult families, on the contrary, are relatively difficult to pay postgraduate tuition fees. They are more willing to go to work and reduce the economic burdens of their families. Their choices reflect students' psychological expectations; students hope to have better lives through receiving higher education. 
We can clearly see from the survey that, compared with arts students, engineering students are more willing to choose postgraduate study. But the general trend is that in all graduate candidates, nearly $70 \%$ of students choose schools according to professional authorities of their chosen majors.

According to the survey sample, we are pleased to see that $60 \%$ of students want to improve themselves through postgraduate education. But it cannot be ignored that nearly $30 \%$ students choose postgraduate education in order to avoid the pressure of employment competition. For college students, postgraduate education is not only a choice of avoiding employment pressure or getting competitive edge, but also a method to get higher social statuses through the social mobility mechanism of higher education.

Suggestions on students' attitude towards postgraduate education. Regardless of family economic conditions, students should carefully consider their choices of becoming postgraduate students. They need to get a clear understanding of employment situation and their prospects after postgraduate study, and find out unfavorable factors hidden behind the craze of postgraduate entrance examination. Correct understandings of them are necessary. Not everyone is suitable to do research. For some students, it is not necessary to choose undergraduate study. The irrational choices of individuals will lead to collective irrationality. The increasing number of graduate students will weaken their comparative advantages in the employment market, and may lead to the decrease of graduate students' salaries.

When choosing schools, students need to pay attention to their own characteristics and abilities, and to treat famous universities rationally. It cannot be denied that top universities have the best teaching abilities, but in order to increase the chances of admission, students need to choose schools and majors which can match their abilities.

It is correct to improve students' educational levels and personal qualities through further study, but it is inappropriate to escape employment pressure temporarily through postgraduate education. We do not advocate this attitude towards study. The issue of employment needs students' carefully consideration.

\section{References}

[1] N.J Xiong, D.H. Zhao, Z.L. Shi, The rational choice of economic man and the flow channel of social man -- an analysis on the heat of postgraduate entrance exam from perspectives of economics and sociology, J. Research On Education Tsinghua University. 4 (2005) 47-54.

[2] B.Y. Zhang, Economic behavior analysis on university students' decision of taking postgraduate entrance examination in light of behavioral economics, J. Journal of Fujian Education Institute. 3 (2009) 34-37.

[3] C.M. Yin, Educational psychology analysis on the heat of postgraduate entrance exam in China from the perspective of learning motivation, J. Higher Education and Research. 6 (2006) 67-70.

[4] H.L. Wang, Social psychology analysis on the heat of postgraduate entrance exam, J. Chinese Hi-tech Enterprises. 21 (2008) 204-207. 